\title{
AS CAUSAS DE EXCLUSÃO DA CULPABILIDADE NO NOVO CÓDIGO PENAL
}

\author{
ALCIDES MUNHOZ NETTO \\ Professor Titular de Direito Penal da Universidade \\ Federal do Paraná.
}

SUMÁRIO: I - INTRODUÇÃO: 1. As dificuldades do tema; 2. A culpabilidade normativa no Código e a classificação de suas excludentes. II. - CAUSAS DE INIMPUTABILIDADE: 3. O critério do Código. 4. A estreiteza do art. 31; 5: A deficiente regulamentação da embriaguês; 6 . A menoridade; 7. A posição da coação moral. III - CAUSAS OBSTATIVAS DO DOLO E DA CULPA: 8 . A ausência de regra acerca do êrro sobre elementos jurídico-normativos do tipo; 9. Natureza e efeitos do caso fortuito. IV - CAUSAS DE EXCLUSÃO OU DIMINUIÇÃO DE CENSURA POR ANORMALIDADES DE MOTIVAÇÃO: 10. Classificação; 11. A fórmula sobre o erro de direito e responsabilidade objetiva.

\section{I - INTRODUÇÃO}

1. De todos os elementos do delito é a culpabilidade que apresenta maiores dificuldades e suscita os problemas de mais árdua solução. Isto se deve, sobretudo, à evolução constante da ciência penal quanto ao conteúdo da ação culpável. (1) Ainda persiste na doutrina a luta entre os que teimam em atribuir à culpabilidade natureza meramente psicológica, divisando no dolo e na própria culpa formas de vinculação psicológica entre o autor e o resultado de sua ação $\left({ }^{2}\right)$ e os que, num conceito verdadeiramente uniriário, encaram-na

A pesquisa de bibliografia em lingua alemã contou com o concurso do Auxiliar de Ensino Prof. Juarez Xavier Tavares, do Departamento de Ciências Penais da U.F.P.

1) R. Maurach assinala não haver outro elemento constitutivo do crime com tantas evoluções em sua elaboração: "A Teoria da Culpabilidade no Direito Penal, vol. 15, pág. 20.

2) Adotam a concepção psicológica, entre outros, Bellavista, II problema della colpevolezza, 1942, pág. 133; Santamaria, Colpevolezza,in Enc. dir., vol. VII, pág. 649; Sebastian Soler, Derecho Penal Argentino, 1956, vol. II, § 39, pág. 72. A grave deficiência desta concepção revela-se quanto à culpa inconsciente, em relação à qual não se encontra qualquer vinculação psicológica entre $\circ$ autor e $\circ$ resultado que nem previu. Isto impossibilita uma concepção psicológica unitária de culpabilidade. 
como juízo de censura incidente sobre o autor, por não se haver abstido da evitável violação à norma. Tal construção amplia o conceito do fato culpável, com a introdução de um elemento normativo comum ao dolo e à culpa, constituído pela exigibilidade de comportamento diverso $\left(^{3}\right)$. Mesmo, porém, entre os adentos desta concepção normativa há assinaladas divergências quanito aos elementos constitutivos da culpabilidade. Uns, na defesa de um conceito normativo puro, a expungem de todo e qualquer fator psicológico. Deslocam, como os finalistas, o dolo e a culpa para a estrutura da ação típica, e consideram como componentes da culpabilidade, a imputabilidade, a possibilidade de consciência da ilicitude do fato e a exigibilidade de uma conduta conforme à norma. ( $\left.{ }^{4}\right)$ Outros, mais fiéis à formulação de REINHART FRANK adotam um conceito de culpabilidade complexo ou misto. Entendem-na composta de fatos psicológicos e juízos de valoração e, como seus elementos, requerem a imputabilidade do autor, sua vinculação psicológica ou normativa ao crime e a normalidade de motivação com a consequente exigibilidade de comportamento diverso. $\left(^{5}\right)$ E óbvio que cada uma destas posições acarreta conseqüências diversas sobre as causas excludentes da culpabilidade, pois dos elementos atribuídos ao comportamento culpável decorrerão os fatores que impossibilitam a respectiva caracterização, isto é, as suas causas excludentes.

Para a análise destas causas perante determinado ordenamento jurídico-positivo, é, portanto, essencial fixar qual a concepção de culpabilidade que the é mais compatível e quais as eximentes que, de suas normas, podem ser deduzidas. Só assim será possível estabelecer se dada hipótese legal de isenção de pena decorre da ausência de culpabilidade, ou da falta de outro componente do delito, ou de simples razão de conveniência. Desta forma, por outro lado, identifica-se qual o componente da ação culposa anulado pela eximente.

2. O novo Código Penal do Brasil harmoniza-se com uma concepção de culpabilidade de índole normativa. Além da imputabilidade e do dolo ou culpa, requer a censurabilidade pessoal para a imposição da pena e a leva em conta em sua medida. Com efeito, a ausência de censura, por inexigibilidade de outra conduta, é que fundamenta a inexistência de culpabilidade na ação necessária com sacrifício de direito igual ou superior ao protegido (art. 25), não obstante subsista

3) Este comum elemento normativo permite incluir na culpabilidade a idéia de reprovabilidade pessoal, que incide quer sobre os comportamentos conscientemente dirigidos à violaçăo de bens jurídicos (dolo), quer sobre a falta de atenção e de cautelas destinadas a evitá-las (culpa).

4) Esta é a posição de Maurach, Welzel, Busch, Stratenwerth e Jescheck.

5) Seguem a formulação de Frank: H. Mayer, Baumann, Sauer, Mezger-Blei, Schwidhäuser e Schönke-Schoröder. 
na hipótese o vínculo psicológico entre o autor e o comportamento $\left.{ }^{6}\right)$. Sob o outro aspecto, a agravação relativamenie indeterminada da pena aos criminosos habituais e por tendência (art. 64) só encontra justificativa na maior censurabilidade que recai sobre tais tipos normativos de autor, em função, não da intensidade da vontade (que é diminuída pelo hábito e pela inclinação ao ilícito), mas da omissão permanente do dever de orientar a formação da personalidade de modo a respeitar os valores afirmados pelo direiro. $\left(^{7}\right)$ Em sentido inverso, a nova atenuante por anterior comportamento meritório (art. 58 , II) parece inspirar-se na menor culpabilidade referível ao autor e ao seu modo de vida. $\left.{ }^{(}\right)$

Embora, através destas e de outras disposições $\left({ }^{9}\right)$, conclua-se ser o Código compatível com concepção normativa de culpabilidade, não parece possível adofá-la ao estilo de MAURACH e outros finalistas ${ }^{(10)}$ como puro juízo de valor, excluindo de seu âmbito o dolo e a culpa. Óbice intransponível à tal solução encontra-se no art. 17, que contém a conceituação do crime doloso ou culposo. Alude a rubrica

6) Na ação necessária exculpante o agente quer o sacrifício do direito alheio, para a salvaguarda do direito próprio ou do terçeiro a quem esteja afetivamente ligado. Subsiste, portanto, o dolo como vontade do fato. Mas não existe censura pessoa!, ante a inexibilidade de conduta diversa.

7) O fundamento da culpabilidade referível ao autor, para justificar a exasper ção da pena ao criminoso habitual ou por tendência, tem, como nota Bettiol, origem moralista na doutrina de Aristóteles, transporta para o Direito Penal por Tesar e Kollmann e aceita por Mezger, Bockelmann, Welzel e outros, Azione e Colpevolezza nelle Teorie dei Tipi di Autore, in Scritti giuridici, 1966, vol. II, pág. 562. Também Eduardo Correia defende tal ponto de vista e o consagrou legislativamente: Direito Criminal, 1963, pág. 325; Código Penal, Projeto da Parte Geral, 1963, pág. 57. A pena aos crimincsos habituais e por tendência encarada então como duplamente retributiva: primordialmente do fato e acessoriamente do hábito ou índole, dada a omissão do delinquente do cumprimento do dever de orientar a formação ou a preparação de sua personalidade, de modo a torná-la apta a respeitar os valores jurídico criminais. Contrapõe-se este critério o sistema adotado na Alemanha, Itália e França que, levando em conta a periculosidade dos delinquentes habituais ou por tendência, impõem-lhes medida de segurança complementar ou substitutiva da pena.

8) Embora a culpabilidade referível ao autor seja insuficiente para a imputação quando desacompanhada da culpabilidade referida ao ato isolado, deve ela influir na gravidade da pena, desde que ao autor se possa censurar a formação de uma personalidade propensa ao delito e hostil às normas de convivência (ver A. Munhoz Netto: Aspectos do Crime Continuado, in Revista da Faculdade de Direito da U.F.P., vol. 12, pág. 1.43 e Erro de Fato e Erro de Direito no Anteprojeto de Código Penal, in Rev. Bras. de Criminologia e Direito Penal, vol. 4, pág. 75). Da mesma forma, o anterior comportamento meritório atenua a pena, ante a menor culpabilidade pelo modo de vida.

9) Há outras disposições do novo Código que confirmam a preferência pela concepção normativa, tais como as que tratam do excesso excusável nas descriminantes (art. 20, $\S 1.0$ ) e do aborto sentimental (art. 130, 11). Em ambos os casos, a impunidade decorre da inexigibilidade de outra conduta.

10) R. Maurach, D. Penal, trad. espanhola de C. Roda, vol. I, pág. 301, § 22; Welzel, Deutsches Strafrechet, 1967, pág. 61; Jescheck, Lehrbuch des Strafrpechts, 1969, pág. 195; Niese, Finalität, Vorsatz und Fahriässigkeit, pág. 53. Construção original encontra-se em Wessels, que trata o dolo e a culpa quer como elementos subjetivos do tipo, quer como elementos da culpabilidade, Strafrecht, Allgemeiner Teil, 1970, pág. 21. 
lateral deste artigo à "culpabilidade", significando que o dolo e a culpa devem ser tidos como formas daquele elemento do crime. Desde que as rubricas integram a lei, constituindo-se em elementos obrigatórios de interpretação ${ }^{11}$ ), a concepção normativa adaptável ao Código é a mista ou complexa, com a inclusão de elementos psicológicos e normativos. ${ }^{12}$ )

Em consequência do que aré aqui se expôs, cremos que, em face do nosso último diploma punitivo, a culpabilidade compõe-se da imputabilidade, do dolo e da culpa e da normalidade da motivação, relacionada esta à exigibilidade de comportamento conforme à norma e à potencial consciência da antijuridicidade. $\left({ }^{13}\right)$ À luz desta estruturō, é que apreciaremos aspectos de algumas das causas de exclusão da culpabilidade no Código Penal de 1969, classificando-as, para tal efeito, em causas de inimputabilidade, causas obstativas do dolo e culpa e causas de exclusão ou diminuição de censura por anormalidade de motivação.

\section{II - CAUSAS DE INIMPUTABILIDADE}

3. Como causas de inimputabilidade, contempla o Código a doença mental ou desenvolvimento mental incompleto ou retardado (art. 31), a embriaguez proveniente de caso fortuito ou força maior (art. 32) e a menoridade (art. 33). Também à coação moral atribui-se - mesmo efeito. Para as primeiras hipóteses prevaleceu o critério biopsicológico, enumerando-se as causas orgânicas e pessoais que podem determinar a incapacidade intelectiva ou volitiva e exigindo-se a sua efefiva constałação, salvo quanto aos menores de dezesseis anos, em relação aos quais a incapacidade é presumida juris et de jure.

Preferiu-se, destarte, o critério tradicional à fórmula jurídico-valorativa, consagrada pelo Código da Checoslovaquia de 1962 e preconizada por JIMÉNEZ DE ASÚA para o Código Penal Tipo da América Latina. $\left.{ }^{14}\right)$ Segundo esĩa fórmula a lei deve prescindir da enumeração

11) A respeito do valor exegético dos tífulos, consulte-se Sebastian Soler, ob. cit., vol. III, § 76, pág. 13.

12) Esta construção, além de adołada por H. Mayer, é aceita por normativistas de outros países, como Bettiol, Diritto Penale, 1969, pág. 340; Eduardo Correia, ob. cit., vol. 1, § 21, pág. 321; A. Quintano Ripollés, Curso de Derecho Penal, 1963, vol. 1, pág. 277; L. Jiménez de Asúa, La Ley y el Delito, 1954, pág. 384; Anibal Bruno, Direito Penal, 1956, t. II, pág. 416; J. Frederico Marques, Curso de Direito Penal, 1956, vol. II, pág. 161, entre outros.

13) Não vemos porque destacar, como elemento autônomo, a possibilidade de consciência do ilícito. Parece-nos mais correto ligá-la à normalidade de motivação: não havendo consciência da ilicitude, desaparece um dos motivos que poderiam atuar sobre o autor, para que se abstivesse da conduta delituosa.

14) Ver El Codigo Penal Tipo para Latinoamerica (atas das 1. a e 2.a reuniões plenárias) Rosário, 1968, pág. 233. 
das causas pelas quais o autor não tenha podido compreender a ilicitude de seu ato e dirigir suas ações, posto que o decisivo para a inimputabilidade é a incapacidade de entendimento ou de auto-governo, não procurada nem previsível ao agente.

A manutenção do critério bio-psicológico, adoíado, aliás, nos recentes Códigos Penais da Argentina e da Alemanha ( ${ }^{15}$ ) tem, evidentemente, o sentido de limitar os casos de inimputabilidade. Com a enumeração das causas de que se deve originar a incapacidade de entender o caráter criminoso do fato ou de determinar-se de acordo com esse entendimento, impede-se $\circ$ afrouxamento da repressão penal pelo abuso no emprego desta excludente. $\left({ }^{16}\right)$

Mas, se de um ponto de vista de política criminal, justifica-se a preocupação em circunscrever o reconhecimento da inimputabilidade às suas hipóteses mais características, sob o prisma da justiça material, fundada na idéia de um Direito Penal da culpa, impõe-se a necessidade de uma fórmula apta a evitar que se presuma a imputabilidade em situações em que, efetivamente, fatores orgânicos ou pessoais, diversos da doença e do retardamento mental, da embriaguez fortuita ou forçada e da menoridade, conduzam à anulação da capacidade de entendimento ou de auto-governo. Do contrário, a ficção de imputabilidade conduzirá à responsabilidade objetiva, incompatível com o princípio do nulla poena sine culpa que deve presidir toda a elaboração penal. Lamentavelmente, o nosso novo Código Penal, no capítulo da inimputabilidade, não realiza esse equilíbrio entre o útil e o justo.

4. Ao tratar, no art. 31, dos inimputáveis, o Código, ao contrário do Ante-projeto "Hungria", não inclui a grave anomalia psíquica entre os fatores biológicos da inimputabilidade. Repetindo o art. 22 do Código Penal de 1940, só menciona, a este título, a doença mental e o desenvolvimento mental incompleto ou retardado.

Tal limitação é anti-científica. Há situações determinantes de incapacidade intelectiva ou volitiva não enquadráveis entre as doenças mentais ou entre as modalidades de desenvolvimento mental incompleto ou retardado. E possível a ausência de capacidade por fatores fisiológicos ou por influxos psicológicos, tais como, o esgotamento total, os delírios de febre, os estados de sonolência intensa, o estado crepuscular de epilepsia, a letargía hipnótica, os estados de choque e outros análogos, em que estão perturbadas as relações normais en-

15) C. P. Argentino, art. 34; C. P. Alemão, § 20.

16) Nos países que mantém a instituição do iúri, pode ser perigosa uma fórmula muito ampla de inimputabilidade. Demonstra-o a experiência brasileira com a indiscriminada aplicação pelos jurados do art. 27, § 4.0, do Código Penal de 1890. 
tre a consciência que o autor tem em si mesmo e do mundo exterior $\left({ }^{17}\right)$. Como salientava MEZGER, para compreender o fenômeno "é preciso partir do "eu consciente do fim", entendido como aquela parte consciente da personalidade, adequada à realidade, em contraste às forças elementares, instintivas e inconscientes. No estado normal de vigília, possui o homem auto-consciência, que de uma parte abrange esie ou consciente do fim e, de outra, as referências do eu ao mundo exterior e com isso ao mundo exterior mesmo. Em casos de uma perturbação de alto grau da consciência, aparece perturbada e interrompida a relação da autoconsciência ao eu e ao mundo externo, de tal modo que fica excluído o influxo normal do eu no mundo exterior". (18) Excepcionalmente, os próprios estados emocionais intensos e as paixões em alto grau (paroxismos, situações produzidas pelo terror, estados de natureza sexual), podem, se aliadas a uma particular excitabilidade do autor, produzir idênticas conseqûências excluindo a imputabilidade. ${ }^{(19)}$

Para atender a estas situações, vários Códigos Penais, sem quebra do critério bio-psicológico, ao lado da doença mental e do desenvolvimento incompleto ou retardado, aludem, como causas biológicas da inimputabilidade, às "graves perturbações de consciência", aos "estados de inconsciência" ou aos "transtornos mentais transitórios". $\left({ }^{20}\right)$ Pela primeira vez destas fórmulas opiaram os elaboradores do Código Penal Tipo para a América Latina. O texto resultou de proposta do saudoso Ministro NELSON HUNGRIA, como representante do Brasil, e apresenta a seguinte redação: "Não é imputável quem, no momento da ação ou omissão, não possuia, em virtude de enfermidade mental, de desenvolvimento psíquïco incompleto ou retardado ou de grave perturbação da consciência, a capacidade de compreender o caráier ilícito do fato ou de determinar-se de acordo com esta compreensão". $\left({ }^{21}\right)$

Como o legislador de 1969 afastou-se da fórmula padrão, aprovada no México, em 1965, considerando-a desaconselhável à realidade brasileira (EM. n. 16), as hipóteses de inimputabilidade decor-

17) A estes e outros estados aludem: Maurach, ob. cit., vol. II, pág. 104; A. Q. Ripollés, ob. cit., vol. I, pág. 323; Eduardo Correia, ob. cit., vol. I, pág. 343.

18) Edmundo Mezger, Tratado de Derecho Penal, trad. de J. A. Rodriguez Muñoz, 1955, vol. II, § 39, pág. 71.

19) No sentido do texto: Maurach, ob. cit., vol. II, pág. 104; Mezger, ob. cit., vol. II, pág. 71; A. Q. Ripollés, ob. cit., vol. I, pág. 323 E. Correia, ob. cit., vol. I, pág. 343; O. Vannini, Manuale di diritto penale, 1948, pág. 477; Bettiol, D. Penale, pág. 387; Eugenio Cuello Calón, Derecho Penal, 1953, vol. I, pág. 505; G. Vidal e J. Magnol, Cours de Droit Criminel et de Science Pénitentiaire, 1949, vol. I, pág. 338; S. Soler, ob. cit., vol. II, pág. 65; A. Bruno, ob. cit., t. II, pág. 539; Guilherme Percival de Oliveira, Estados Afetivos e Imputabilidade Penal, 1958, pág. 117 ss.

20) Cod. Alemão de 1969, § 20; Cod. Argentino, art. 34; Cod. Espanhol, art. 8.0, I.

21) El Codigo Penal tipo para Latinoamerica, págs. 254 e 491. 
rentes de perturbação de consciência terão que ser solucionadas de um dos seguintes modos: ou serão irrelevantes, o que conduzirá a uma ficção de imputabilidade e, pois, à responsabilidade objetiva, que a Exposição de Motivos diz que se procurou proscrever $\left({ }^{22}\right)$; ou serão considerados para a exclusão da previsibilidade e, portanto, do dolo e da culpa, através de construção exegética em torno do art. 18 do Código, referente a inexistência de crime por caso fortuito ou força maior, matéria de que trataremos adiante.

5. Observações análogas cabem quanto à regulamentação da embriaguez. Desde que 0 art. 32 só menciona a embriaguez proveniente de caso fortuito ou força maior, segue-se que, em princípio, não excluirão a culpabilidade a embriaguez voluntária ou culposa, mesmo que desacompanhadas de anuência, previsão ou previsibilidade do ulterior comportamento delituoso. Ora, também neste particular subsistirá uma imputabilidade ficta, inadmissível num direito penal da culpa. A supressão pelo Código do dispositivo que o Anteprojeto consignava a respeito (art. $31, \S 1 .^{\circ}$ ) não pode ser justificada com apoio na teoria das actiones liberae in causa. É fartamente sabido que tal teoria só fundamenta a punição de delitos cometidos em estado de inimputabilidade, nos casos em que, no anterior momento de imputabilidade, o autor haja querido, aceito ou previsto a prática do crime, ou, pelo menos, que esta lhe fosse previsível. $\left({ }^{23}\right)$ Na embriaguez voluntária ou culposa pode faltar qualquer destas atitudes. A vontade ou imprudência no embriagar-se, não implica na vontade ou previsibilidade quanto ao cometimento de um delito. A exceção da actio libera in causa só é aplicável, pois, aos casos de embriaguez preordenada ou, extensivamente, aos de embriaguez com anuência ou previsibilidade do crime.

É verdade que a embriaguez ocupa um lugar de destaque na etiologia dos crimes, tendenie a acentuar-se pela disseminação no uso de tóxicos e entorpecentes. ${ }^{(24)}$ Mas também é certo que o Direito Penal não é o único nem o mais eficaz instrumento para combater a criminalidade alcoólica. Tal luta reclama um complexo de medidas profilático-preventivas, mais do que medidas repressivas. De qualquer forma, na parte que toca ao direito punitivo, em lugar de presumir-se

22) Exposição de Motivos do C. Penal de 1969, n. 3.

23) Ver o excelente trabalho do Prof. Anibal Bruno: Embriaguez voluntária e culposa e responsabilidade penal, in Rev. Bras. de Criminologia e Direito Penal, vol. 7, pág. 19 is.

24) Göppinger, in Kriminologie, 1971, aponta as seguintes porcentagens de delitos praticados sob influência alcoólica: violação de domicílio, em 1958, 30\%; lesões corporais, em 1958, 26\%; delitos sexuais, em 1958, 33\%, em 1967, $72 \%$; furto de automóvel, em 1960, 15\%; em 1961, 43\%; em 1967, 49\%; injúria, em 1965, 31\%; ameaça, em 1965, $68 \%$; favorecimento pessoal, em 1967, 11\%; roubo, em 1967, 65\%; incêndio, em 1967, $17 \%$ (tabela I, pág. 155). 
situações de imputabilidade, teria sido preferível que se cogitasse de introduzir em nossa legislação um crime de perigo concreto de embriaguez, como o criado na Alemanha em 1933, pelo $\S 330$ a, acrescentando ao Código imperial e mantido no novo Código de 1969. Melhor do que prever, como crime de perigo abstrato ou presumido (25), a embriaguez ao volante (art. 289), teria sido incriminar a açăo perigosa de embriagar-se dolosa ou culposamente, vindo, em estado de inimputabilidade, cometer ação penalmente sancionada. Mesmo em se considerando, em tal figura, o delito cometido pelo embriagado como condição objetiva de punibilidade $\left({ }^{26}\right)$, esta solução, sem debilitar a defesa social, seria menos comprometedora quanto à idéia central da não imposição de pena sem culpabilidade.

6. Quanto às disposições sobre a menoridade, dispensamo-nos de apreciá-las, em face da comunicação feila pelo Prof. Benjamin Moraes Filho ao $4 .^{\circ}$ Congresso Nacional de Direito Penal (Recife, 1970), de que o Ministério da Justiça já tem por resolvida a restauração da regra do art. 23 do Código anterior, que proclama inimputáveis os menores de dezoito anos.

7. A coação moral, tal como está disciplinada no art. 24 a do Código de 1969, tem que ser considerada causa de inimputabilidade. E que ali se estabelece que a vis compulsiva deve suprimir "a faculdade de agir segundo a própria vontade", isto é, a capacidade de autogoverno. A cláusula não é das mais felizes. Em primeiro lugar porque, embora considerada por alguns, como força anímica irresistível que elimina a imputabilidade $\left({ }^{27}\right)$, a coação moral é tida pela doutrina

25) O X.० Congresso Internacional de Direito Penal, Roma, 1969, aprovou conclusão de que, quanto aos chamados delitos de perigo presumido, a presunção seja meramente relativa, de modo a consentir prova contrária. Melhor, entretanto, é limitar ao máximo os tipos delituosos de perigo presumido, condicionando sempre a punibilidade à efetiva constatação do perigo decorrente da ação. É excessivamente rigoroso ○ art. 289 do novo Código ao incriminar o simples dirigir em estado de embriaguez, pois nem sempre tal atividade acarreta riscos à incolumidade pública, sabido como é que os efeitos da ingestão de alcool variam de indivíduo para indivíduo, havendo os que, embriagados, dirigem com redobradas cautelas.

26) Segundo o $\S 330$, a, do Código Alemão, quem dolosa ou culposamente se coloca em estado de embriaguez causadora de incapacidade de culpa, será punido com pena privativa de liberdade até cinco anos ou com pena de multa, se neste estado cometer uma ação punível. A pena, contudo, não pode ser mais grave que a cominada à prática dolosa de tal ação. Não é fácil harmonizar esta figura delituosa com o primado do nulla poena sine culpa: a culpabilidade não pode ser relacionada nem com ação de embriagar-se, que em si mesma, é juridicamente neutra, nem com o delito cometido em estado de embriaguez, dada a inimputabilidade em que, então, se encontra o autor. Welzel, contudo, soluciona o problema nos domínios da culpa, ao exigir que o autor, embriagado, tenha tendência para a prática de fatos puníveis e que conheça tal tendência (ob. cit., pág. 453). Parece que, nesta construção, joga-se com a teoria da actio libera in causa, exigindo-se, pelo menos, a previsibilidade da prática do delito em estado de embriaguez, com o que identifica-se o conteúdo culpável do comportamento.

27) H. Mayer, Straferecht, pág. 194, apud A. Bruno, D. Penal, t. II, pág. 551, nota 1. 
dominante como causa de exculpação baseada na inexigibilidade de outra conduta $\left({ }^{28}\right)$ ou, como querem JESCHEK e outros, como causa de inculpabilidade fundada na diminuição da antijuridicidade e da culpabilidade, em que a inexigibilidade de outra conduta funciona como princípio regulador. $\left({ }^{29}\right) \mathrm{O}$ próprio autor do Anteprojeto de que proveio a fórmula do Código relacionara a coação moral à inexígibilidade de outra conduta. Realmente depois de observar que, na coação moral, "o coagido contribui com sua vontade (coactus tamem voluit); mas como esta não é livre, deixa de ser censurável e, poríanto, culpável" afirmava HUNGRIA que "a coação moral exerce-se pela intimidação ou ameaça de um mal grave, que o coagido não possa arrostar ou cuja paciência não lhe possa ser razoavelmente exigida". $\left.{ }^{(30}\right) \mathrm{Em}$ segundo lugar, a fórmula do Código revela-se insuficiente porque não é fácil, senão praticamente impossível, imaginar uma coação moral que suprima a capacidade de vontade do coacto. Para evitar a continuação ou a repetição do mal que já lhe foi infligido ou que é ameaçado, a si próprio ou a pessoa que the seja cara, o coagido decide-se pela prática do crime que the exige o coator. Ora, nestas hipóteses, que são as de típica coação moral, há capacidade de vontade do coagido, que opta entre duas alternativas: a de praticar - crime ou de sofrer o dano. Só quando ocorra vis absoluta, com constrangimento físico insuperável, é que a vontade mesmo imperfeita do coacto não participa do acontecimento. Mas, então, passa-se do setor das excludentes de culpabilidade, para hipótese de ausência de ação, matéria regulada em outro dispositivo (art. 23). Para evitar que a aplicação da excludente possa ficar limitada à hipóteses impossíveis, seria útil que em vez de aludir a lei à supressão da faculdade de agir segundo a própria vontade, condicionasse a eficácia escusante da coação à razoável inexigibilidade de conduta diversa.

\section{III - CAUSAS OBSTATIVAS DO DOLO E DA CULPA}

8. O èrro quanto à cïrcunstância que consfitui o fato, previsto na primeira parte do art. 21, é, indiscutivelmente, fator impeditivo da formação do dolo e, se escusável, ainda, da culpa em sentido estrito ( $\left.{ }^{31}\right)$ A falta de representação ou a representação errônea da realidade quando incide sobre um dos componentes do tipo, vicia

28) Baumann, ob. cit., pág. 444; Maurach, D. Penal, vol. II, pág. 65; Shönke - Schröder, Strafgesetsbuch Kommentar, 1957, pág. 287; Mezger-Blei, Strafrecht, Sutudienbuch, 1968, pág. 220; Welzel, ob. cit., pág. 172.

29) Jescheck, ob. cit., pág. 315 ss; Wessels, ob. cit., pág. 64; Bockelmann, Strafrechtliche Untersuchungen, 1957, pág. 84 ss; Armin Kaufamann, Die Dogmatik der Unterlassungs delikte, 1959, pág. 156 ss.

30) Nelson Hungria, Comentários ao Código Penal, 1949, vol. I, págs. 420 e 423.

31) Separamos o erro sobre componente do tipo, do erro sobre descriminante (art. 21, 2.a parte). Este afeta a consciência da ilicitude, relacionando-se à normalidade de motivação. 
o processo formativo de vontade e impede a consciência da tipicidade, que é elemento intelectual do dolo. Se o erro é insuperável, também se torna impossível a previsibilidade da prática de uma ação típica, inexistindo, em conseqüência, culpa.

Embora reconhecida, na Exposição de Motivos (n. 12, a maior perfeição técnica da divisão entre erro de tipo e erro de proibição, preferiu o Código manter a superada dicotomia entre erro de fato e erro de direito $\left({ }^{32}\right)$ a pretexto de que a construção mais científica é complexa e estranha à nossa doutrina. Istio não impede, entretanto, que a modalidade de erro regulada pela primeira parte do art. 21 seja relacionada ao tipo, posto que incide sobre circunstância que constitui o fato delituoso, isto é, sobre componente típico do crime.

Ocorre, contudo, que a disposição legal só alude à circunstância de fato constitutiva do crime, deixando, portanto, sem solução expressa o erro sobre elementos jurídico-normativos do tipo, isto é, aqueles cuja percepção implica sempre em valoração jurídica da parte do autor (vg. o caráter alheio da coisa, no crime de furto; a qualidade de funcionário público, nos crimes contra a administração; a noção de documento, como objeto dos crimes de falso). Estes elementos, que tem que ser abrangidos pela representação do tipo que informa o dolo, envolvem uma apreciação jurídica e não apenas uma percepção fáctica. Em conseqüência, o erro que sobre os mesmos incida não poderá ser considerado como erro sobre circunstância de fało. Será antes um erro de direito embora com incidência sobre um componente do tipo. Se, logicamente, tal erro também exclui o dolo, por falta de consciência da tipicidade, será imperativo reconhecer-lhe eficácia.

Como não se repetiu, no novo Código, a regra da total irrelevância da falta de conhecimento ou da errada compreensão da lei (art. 16 do Código de 1940) e desde que a nova norma sobre o error iuris circunscreve-se à ignorância ou erro que conduzem à suposição de licitude do fato e, portanto, a autêntico erro de proibição, será possível chegar-se à isenção de pena, nos casos de erro escusável sobre elementos jurídico normativos do tipo, recorrendo à construção que equipara o erro de direito extra-penal ao erro de fato, conforme preconiza a Exposição de Motivos. $\left.{ }^{(33}\right)$

32) Ver Alcides Munhoz Netto, $\circ$ Erro de Fato e o Erro de Direito no Anteprojeto de Código Penal, in Rev. Bras. de Criminologia e Direito Penal, vol. 4, pág. 55 ss; Jorge Figueiredo Dias, O Problema da Consciência da llicitude em Direito Penal, 1969, pág. 61.

33) A Exposição de Motivos do Código novo consigna que "o entendimento geral da doutrina e da jurisprudência em relação ao erro de direito extra-penal, equiparado ao erro de fato, elimina o principal inconveniente da ampla disposição do Código vigente quanto à irrelevância do error iuris (n. 12). 
Esta solução entretanto apresenta duplo inconveniente: subordina o reconhecimento da inexistência do dolo por erro de direito exirapenal ao sabor das variações da jurisprudência e não atende satisfatoriamente as hipóteses de erros sobre elemenios típicos jurídico no:mativos de índole penal. Com efeito, não havendo no Código regra expressa a respeito da equiparação do erro de direito extra-penal ao erro de fato, como sucede no Código Rocco (art. 47), nenhum juiz estará obrigado a aceitá-la. $\left({ }^{34}\right)$ Não conduz a tanto a mera referência à equiparação contida na Exposição de Motivos, pois esta não integra a lei nem se reveste de caráter cogente. ( ${ }^{35}$ ) Quanto ao segundo aspecto, não há quem não perceba como é arbitrária a limitação da eficácia excusante apenas ao erro sobre elementos típicos normativos não penais. Na estrutura do tipo podem figurar elementos cuja percepção envolva valoração jurídico penal (v. g. o caráter criminoso do fato imputado, no delito de calúnia; a ciência de que a coisa recebida ou ocultada é produto de crime, na receptação e no favorecimento real). O erro sobre estas circunstâncias impede a formação do dolo da mesma forma que a falsa representação de qualquer conceito jurídico extra penal, incorporado à determinada descrição típica. Não há, assim, como tratar diversamente as duas hipóieses. Aliás, para evitar a incongruência, parte da doutrina italiana, ao arrepio do texto expresso do art. 47, última parte, do diploma peninsular, reclama a impunidade também para o erro sobre elementos típicos normativos de natureza jurídico penal. $\left({ }^{36}\right)$

Acreditamos que melhor do que recorrer à discutida equiparação entre o erro de direito exirra-penal e o erro de fato $\left({ }^{37}\right)$, será resolver o problema do erro sobre elementos típicos jurídico-normativos através da própria conceituação do dolo. O querer ou o anuir que o integram não constituem processos sem pressupostos. Conforme MAURACH um querer carente de pressupostos constitui não dolo, mas

34) Entre nós, a equiparação do erro de direito extra-penal ao erro de fato é defendida por Basileu Garcia, Instituições de Direito Penal, 1954, vol. 1, pág. 276; J. Frederico Marques, ob. cit., vol. II, pág. 244; E. Magalhães Noronha, Direito Penal, 1959; vol. I, pág. 193; Anibal Bruno, D. Penal, t. II, pág. 497. Dos reflexos desta doutrina em alguns tribunais, sirva de exemplo a decisão da corte paulista, considerando não punível a título de falsidade ideológica, por ausência de dolo, pessoa que, ao registrar como legítimos os filhos que teve com a amásia, supos que a palavra "legítimo" significava autêntico, isto é, que era ele realmente o pai, in Rev. For. vol. 196, pág. 200.

35) As exposições de motivos, como observa A. Bruno, valem só como interpretação doutrinária e sua eficácia resulta da convicção que tenham podido criar no espírito do julgador.

36) Ver Scipione Piacenza, Errore ed Ignoranza di Diritto in Materia Penale, 1960, pág. 29, n. 2.

37) Negam efeitos ao erro de direito extra-penal: A. Bento de Faria, Código Penal Comentado, 1958, vol. II, pág. 174; A. J. da Costa e Silva, Código Penal, 1943; vol. I, pág. 129; Galdino Siqueira, Tratado de Direito Penal, 1947, vol. 1, pág. 391 e Nelson Hungria, ob. cit., vol. I, pág. 391. 
instinto. $\left({ }^{38}\right) \bigcirc$ pressuposto do dolo é a ciência pelo agente de que a ação querida ou consentida corresponde a um falo delituoso. Sem esta previsão inexiste o dolo, sendo indiferente que ela falte por erro de fato ou por erro de direito sobre elementos jurídico normativos, ainda que de natureza penal.

O que importa salientar, porém, é que deixando a solução do problema do erro sobre elementos típicos normativos a cargo de construções exegéticas, o novo Código regulou de maneira imperfeita e insuficiente a exclusão do dolo pelo erro.

9. No setor das causas obsiativas do dolo e da culpa, cumpre examinar ainda se entre elas inclui-se o caso fortuito a que alude 0 art. 18 do novo Código. O dispositivo, situado entre os artigos que tratam da culpabilidade e de sua exclusão, declara não haver crime se o fato resulta de caso fortuito. Como no sistema do Código, as expressões "não há crime" são empregadas no sentido de exclusão da antijuridicidade, a redação do dispositivo susciła, desde logo, indagação a respeito de qual dos elementos estruturais do delito fica excluído na hipótese. O problema não é de solução fácil em vista das divergências filosóficas e jurídicas quanto ao que seja caso fortuito.

Em filosofia distinguem-se três conceitos de caso fortuito que se cruzaram em sua história: a) o conceito subjetivista, que o considera como acontecimento imprevisível e indeterminável, devido à ignorância e a confusão do homem; b) o conceito objetivista, que atribui o acontecimento causal à mescla ou à intercessão de causas e, c) a interpretação moderna, segundo a qual caso fortuito é a insuficiência de probabilidades na previsão. Deste ponto de vista, que remonta a HUME o caso fortuito é um juízo, no qual a probabilidade não tem a suficiente relevância com respeito à previsibilidade de um acontecimento. $\left({ }^{39}\right)$ No campo jurídico penal as opiniões também se dividem. O caso fortuito ora é considerado como o acontecimento que se incumbe, por sua conta exclusiva, do resultado antijurídico, excluindo, portanto, a causalidade $\left({ }^{40}\right)$, ora como a impossibilidade de previsão e de conhecimento, referível, pois, a aspectos psicológicos do crime. ${ }^{41}$ )

Entendemos que caso fortuito não equivale à ausência de causa.

38) R. Maurach, Tratado, vol. I, pág. 31.

39) Nicola Abbagnano, Diccionario de Filosofia, pág. 125.

40) Pela exclusão da causalidade, F. Grispigni, Diritto Penale Italiano, 1947, vol. II, pág. 112; Nelson Hungria, ob. cit., vol. I, pág. 313; J. Frederico Marques, ob. cit., vol. 2, pág. 233.

41) Encarado o caso fortuito como impossibilidade de previsão: F. Alimenta, La Colpa nella Teoria Generale del Reato, 1947, pág. 66; Mendes Pimentel, Liçōes de Direito Criminal, 1954, pág. 53; Esther de Figueiredo Ferraz, Os delitos qualificados pelo Resultado, 1948, pág. 66. 
Como salienta BETTIOL, no mundo fenomênico nada é devido ao acaso. Todo o acontecimento é necessariamente ligado à uma série de acontecimentos anteriores que, por sua vez, determinam acontecimentos sucessivos. Os acontecimentos naturais não podem ser qualificados como fortuitos: são frutos de fatais leis físicas que determinam situações de dano ou de perigo. O fortuito é sempre relacionado a uma ação humana. Por ele não se exclui a causalidade, mas a culpabilidade. $O$ que está fora do nexo causal não pode ser levado em conta para os fins penais. A relação causal no fortuito existe, o que falta é a possibilidade de uma motivação diversa, pela impossibilidade de prever o evento lesivo como consequiência da própria ação ou omissão. ${ }^{42}$ )

Considerado como acontecimento imprevisível, o caso fortuito caracteriza-se pela ausência de culpa, que tem na previsibilidade a sua essência, e de dolo, que não existe sem representação. Trata-se, pois, de causa obstativa de ambas as formas de culpabilidade. Nem seria possível entendê-la de outra forma no sistema do Código. Se o efeito do caso fortuito fosse a exclusão da causalidade, não haveria necessidade de um dispositivo especial que assim declarasse. Quando o comportamento do autor não é causa, a isenção de responsabilidade fatalmente decorre da aplicação, a contrario sensu, da regra sobre a relação causal, consignada no art. 13. Não foi, aliás, por outro motivo, que HUNGRIA, para quem fortuito significa não ligado causalmente ao comportamento humano, impugnou, por supérfluo, na Comissão Revisora do Código de 1940, o dispositivo do Projeto Alcântara Machado sobre a exclusão da punibilidade nas hipóteses de caso fortuito e força maior. $\left(^{43}\right)$ Realmente, dispositivo deste teor só tem sentido quando se considere o caso foríuito como impediente da previsibilidade.

A excludente de que estamos tratando poderá ter aplicação quer aos casos em que a previsibilidade é excluída por circunstâncias externas $\left({ }^{44}\right)$, quer às hipóteses em que é impedida por fatores pessoais do autor. Emprestando-se-lhe tal amplitude, o caso fortuito servirá para atenuar a já apontada deficiência do Código, quanto ao tratamento dos inimputáveis por grave perturbação de consciência, ou por embriaguez voluntária ou culposa. Ainda que o sentido restrito dos artigos 31 e 32 não permita fundar a isenção penal na própria

42) D. Penale, pág. 436.

43) Comentários, vol. I, pág. 313.

44) Como hipótese clássica de caso fortuito, Bettiol cita o caso apresentado por Frosali e Santoro, do maquinista de trem que, por um fenômeno de fosforecência, verde, em vez de vermelha, a luz do semáforo, e, iludido, avança com o comboio, provocando um desastre. D. Penale, pág. 438. 
inimputabilidade, como seria correto $\left({ }^{45}\right)$ tem que se reconhecer a ausência de culpa, quando o autor, em virtude de um estado mental não procurado nem previsível, fique sem capacidade de entendimento e, portanto, sem condições de prever a realização da ação típica.

E óbvio que para que prevaleça a extensão da eximente do caso fortuito às hipóteses de impossibilidade de prever por grave perturbação de consciência, a avaliação da previsibilidade terá que ser feita, não com o critério do "homem médio", aliás, hoje desacreditado (46) mas, a vista das condições do sujeito que atua. Valem a respeito as judiciosas considerações de BETTIOL: "é o homem, concreta realidade, que age, que quer, que prevê, que vai preso, que é fuzilado, enforcado ou decapitado: não o "homem médio", perigosa abstração que deve ser possivelmente eliminada do setor do direito penal. É, pois, fortuito tudo aquilo que supera a previsibilidade do homem singular, posto que a exigibilidade não pode relacionar-se senão ao homem como individualidade psicofísica. E, assim, aquilo que é fortuito para um indivíduo pode não o ser para outro: tudo depende das possibilidades concretas de representação, de previsibilidade do evento lesivo como conseqüência da própria ação ou omissão. $\left.{ }^{47}\right)$ Adotado este critério de avaliação da previsibilidade, será reconhecível a isenção penal sempre que as graves perturbações de consciência impeçam a previsibilidade do comportamento. É este um recurso exegético, considerado válido pelo $\mathrm{IV}^{\circ}$ Congresso Nacional de Direito Penal. $\left({ }^{48}\right)$

\section{IV - CAUSAS DE EXCLUSÃO OU DIMINUIÇÃO DE CENSURA POR ANORMALIDADE DE MOTIVAÇÃO}

10. A anormalidade de motivação, com reflexos sobre a existência ou o grau de censurabilidade, configura-se, a nosso ver, sempre que o autor não possa adequar o seu comportamento à norma, ou pela impossibilidade de conhecê-la $\left(^{49}\right)$ ou porque, embora conhecendo-a, haja sido levado a violá-la por uma situação de perigo, de medo ou de compulsão. Realmente, não se pode falar em motivação normal, quando ao agente era impossível conformar sua vontade aos mandamentos e proibições jurídicas que não podia conhecer. Da mesma forma, motivação normal não há, quando, pela situação especial

45) Supra, n. Os 4 e 5.

46) Ver crítica ao critério do homem médio em Miguel Reale Júnior, dos Estados de Necessidade, 1971, pág. 46.

47) D. Penale, pág. 438.

48) Neste exato sentido, o IVo Congresso Nacional de Direito Penal (Recife, 1970), aprovou tese oficial do autor. Ver Alcides Munhoz Netto, A Culpabilidade no Novo Código, in Revista da Faculdade de Direito da U.F.P., vol. 13, pág. 139 ss.

49) Miguel Reale Júnior, ob. cit., pág. 42. 
em que se encontrava o autor, dele não se pode esperar um comportamento conforme aos imperativos jurídicos. Nestes casos, ou os freios inibitórios à conduta delituosa não chegaram a se formar ou, in concreto, perderam sua eficácia, pelo que o juízo de reprovabilidade fica excluido ou, pelo menos, arenuado. Consideramos causas de exclusão ou diminuição de censura por anormalidade de motivação as hipóteses de falta de consciência da ilicitude e as situações de inexibilidade de outra conduta. Perante o Código de 1969, este esquema nos conduz ao exame da suposição de licitude, por erro sobre descriminante (art. 21, 2. a parte) ou por erro de direito (art. 20). Também caberia analisar, como casos de inexigibilidade, ação necessária exculpante (art. 25), a obediência hierárquica (art. 24 b) e o excesso excusável nas descriminantes (art. 30, § $1 .^{\circ}$ ). Tal análise, todavia, ultrapassa o plano deste trabalho.

11. Sobre a falta de consciência da antijuridicidade o Código adota um tratamento curioso: isenta de pena a falta de conhecimento da ilicitude, por suposição de legitimidade da ação, decorrente de erro sobre descriminante (art. 21 última parte) e só permite a ałenuação de pena, quando tal suposição decorre de erro de direito, ainda que este seja excusável.

$\mathrm{Na}$ ciência penal, os efeitos da falta de consciência da ilicitude variam conforme a posição que a este fator se atribua na estrutura da conduta punível. A doutrina alemã, que maior apuro técnico alcançou na matéria, regisira a respeito três posições: a da teoria do dolo; a da teoria extrema da culpabilidade e a da teoria da culpabilidade limitada. $\left({ }^{50}\right)$

Segundo a primeira teoria, a consciência da antijuridicidade do fato é elemento do dolo, ao lado do conhecimento dos elementos objetivos do tipo. Em conseqüência, a falta de conhecimento da ilicitude, por erro de direito ou por erro de fato, é causa de exclusão desta forma de culpabilidade e, se excusável, até da culpa em sentido estrito. ( $\left.{ }^{51}\right)$ A esta teoria opõe-se que não assegura suficientemente a defesa social, porque, sendo a punição da culpa excepcional, ficariam impunes todos os delitos só previstos na forma dolosa, cometidos com falta de consciência da antijuridicidade, ainda que tal falta decorra de total despreocupação do autor relativamente às exigências da ordem jurídica. Com isso seriam injustamente beneficiados os criminosos brutais e insensíveis, isto é, os de maior irreflexão ou

50) A respeito das teorias sobre o erro de proibição ver Maurach, A Teoria da Culpabilidade no D. Penal Alemão, loc. cit. e Alcides Munhoz Netto, O Erro de Direito e o Erro de Fato no Anteprojeto de Código Penal, loc. cit..

51) E. Mezger, ob. cit., vol. II, pág. 94; Wilhelm Sauer, Derecho Penal (P. General), trad. de J. del Rosal, 1956, pág. 229. 
imprudência. Para sanar tal inconveniente pensou-se, de início, na criação de um crimen culpae, que nada mais seria do que uma culpa de direito, fundada na negligência do sujeito na representação da ilicitude da ação e, cogitou-se depois em presumir o dolo, se a falta de representação da antijuridicidade derivasse de cegueira jurídica ou animosidade ao direito, ou seja, de aititudes incompatíveis com uma razoável concepção de direito e injusto. ( $\left.{ }^{53}\right)$ Mas estas soluções não são aceitáveis: a culpa jurídica é dificilmente concebível em certa categoria de delitos, como os fraudulentos; e o conceito de cegueira ou hostilidade sobre ser demasiadamente incerto, leva a fingir um dolo, que, segundos os próprios partidários da teoria que analisamos, não se configura. Esta ficção de dolo, evidentemente, não se compadece com o princípio fundamental do nulla poena sine culpa. $\left({ }^{54}\right)$

A reoria extrema da culpabilidade, elaborada dentro do esquema da teoria da ação finalista, desloca o conhecimento da antijuridicidade da estrutura do dolo, (que, para o finalismo, faz parte da ação típica) e o situa na culpabilidade, como um dos elementos do juízo de reprovação. E como tal juízo não é um fato psicológico, mas um juízo puro de valor, não será exigível uma consciência atual, bastando uma consciência potencial da antijuridicidade, vale dizer, a simples possibilidade de se dar conta do caráter ilícito do comportamento. $\left({ }^{55}\right)$ A grande vantagem desta teoria, segundo MAURACH, seria a de impedir as falhas inevitáveis da teoria do dolo, não permitindo espaços vazios no direito, nem brechas no sistema dos fatos puníveis. Sustenta-se, então, que na medida da desculpabilidade da falta de consciência do ilícito, fica atenuada a censurabilidade, que poderá desaparecer, dando lugar à absolvição, se o sujeito não teve sequer a possibilidade de se por a par do estabelecido pela norma proibitiva. $\left({ }^{56}\right)$

Para a teoria da culpabilidade limitada, a consciência da antijuricidade também não integra o dolo, sendo a sua mera possibilidade elemento para o juízo de censura. Mas os seus partidários distinguem entre a ignorância da ilicitude por erro de direito (vg. o agente supõe a vigência de uma norma que se existisse justificaria sua ação) e a que decorre da errônea suposição de uma siliuação de fato que justi-

52) E. Mezger, Probleme der Strafrechtserneuerung, apud K. Siegert, II Diritto Penale Nella Recente Dottrina Tedesca, in Riv. Italiana di D. Penale, 1952, pág. 316, n.0 3; W. Saver, ob. cit., pág. 271.

53) Esta construção foi proposta em 1952, por E. Mezger, Strafrecht, Allgemeiner Teir, Ein Studienbuch, apud J.C. Roda, El conocimiento de la antijuricidad en la teoria del delito, 1952, pág. 62.

54) Neste sentido, a procedente crítica de Maurach, A teoria da culpabilidade, loc. cit.

55) Welzel, ob. cit., § 19; Maurach, A teoria da culpabilidade, loc. cit..

56) Idem. 
ficaria a ação (vg. supõe uma situação de legítima defesa, representando-se uma agressão irreal). Na primeira hipótese, subsiste o dolo, atenuando-se ou excluindo-se a censurabilidade segundo a sua desculpabilidade; na segunda, o dolo fica excluído, só subsistindo culpa, se $\circ$ erro for vencível. A teoria da culpabilidade limitada, apresenta-se, assim como uma posição de compromisso entre a teoria do dolo e a teoria extrema da culpabilidade e seu grande defeito é a desigualdade no tratamento de situações análogas (erro vencível de direito e erro vencível de fato, ambos quanto a antijuridicidade da ação). Com efeito, pela aplicação desta teoria, a legítima defesa putativa por erro de fato, sobre a atualidade da agressão, elimina o dolo e, se vencível, o agente será punido a título de culpa. Ao contrário, se a legítima defesa putativa decorrer de erro sobre a ilicitude da agressão, isto é, de erro de direito, persiste o crime doloso, bem como a punição a este título, que somente poderá ser atenuada ou até excluída. ${ }^{(57)}$

Não obstante a incongruência de tais resultrados, esta última construção é que se adapta ao sistema do novo Código. Em verdade, não é cabível, perante o seu texto, incluir a consciência da antijuridicidade no dolo, pois pelo art. 20 a suposição da licitude do fato, que é a contrapartida do conhecimento do injusto, não impede a punição a tal título. Ainda que acreditando ser o fato permitido ou penalmente indiferente, doloso será o comportamento do autor, se a falta de consciência da antijuridicidade decorrer de ignorância ou erro na interpretação da lei. Só se derivada de erro de fato, quanto aos pressupostos de uma descriminante, é que a suposição de licitude impedirá a punição a título de dolo (art. 21, última parte). Mesmo que tal erro seja vencível e, portanto censurável, o agente só responderá por culpa, se o fato for punível como crime culposo (art. $21 \S 1 .^{\circ}$ ). Como não há diferença substancial entre a suposição de licitude a que alude o art. 20 e a suposição de legitimidade a que se refere o art. 21, última parte, é difícil justificar a disparidade de tratamento de ambas as situações. É certo, como observa JORGE FIGUEIREDO DIAS, que a falta de consciência da ilicitude por errônea compreensão do direito revela uma distonia entre os critérios de valor da consciência e os da ordem jurídica, enquanto que a errônea aceitação de pressupostos de uma descriminante decorre da omissão do dever de se informar sobre a realidade circunstancial da situação em que se atua. $\left({ }^{58}\right)$ Mas esta diferença diz respeito à causa de cada um dos erros e não aos seus efeitos. No que toca às consequiências, não há como fugir da seguinte alternativa: ou a consciência de antijuridicidade não integra o dolo e

57) Ver Juan Cordoba Roda, ob. cit., pág. 112.

58) O problema da Consciência da llicitude em D. Penal, págs. 411/2. 
a sua ausência, seja por erro de direito ou de fato, só será levada em conta para a atenuação ou exclusão da pena ante a diminuição ou ausência de censurabilidade; ou a consciência da antijuridicidade faz parte do dolo e, à sua falta, por ignorância da ilicitude ou suposição de uma descriminanie, só será cabível a imputação a título de culpa em sentido estrito.

Todavia, quanto ao erro sobre a antijuridicidade da conduta, o defeito maior do Código não reside em impossibilitar um tratamento unitário ao erro de proibição decorrente de cada uma das situações atrás apontadas. Afinal, a equiparação entre o erro sobre descriminantes e o erro de faro incidente sobre elementos do tipo é viável quando se reviva a superada concepção de elementos negativos do tipo. $\left.{ }^{59}\right)$ Dentro deste ponto de vista, reconhecendo-se que o tipo além dos elementos positivos compõe-se também da ausência de causas de justificação, o dolo terá que abranger, além da representação dos elementos constitutivos da figura delituosa, a de que não ocorre em concreío qualquer situação que exclua a antijuridicidade. Desta forma tanto o erro sobre os elementos estruturais do fato típico, quanto o erro sobre descriminantes, serão erros de tipo, contrapostos ao erro de proibição, que ficaria circunscrito à ignorância da ilicitude por erro de direito. O maior defeito do Código, em nosso entendimento, consiste em não permifir a isenção de pena nem mesmo quando a ignorância da ilicitude, por erro de direito, seja excusável e, pois, não censurável.

Com efeito, se a suposição excusável só permite a atenuação ou sua substituição por outra menos grave, como determina o art. 20, isto significa que a lei presume sempre uma censura pessoal sobre quem ignora a ilicitude por erro de direito. Ora, esta suposição é injustificável. Se, em muitos casos, o erro acerca da proibição decorre de culpa pela formação de uma personalidade hostil ou indiferente aos imperativos do direito, isto é, de condições que podem ser reprovadas ao autor, existem em contraposição, outras hipóteses em que $\circ$ erro de direito que leva à suposição de licitude não permite qualquer juizo de censura. Para estas últimas situações, a solução correła é a total isenção de pena. Como conclui JORGE FIGUEIREDO DIAS, "age sem culpa quem pratica o fato, sem consciência da sua ilicitude, se o erro lhe não for censurável; se o erro for censurável será o agente punido a título de dolo, podendo no entanto a pena ser especialmente atenuada". $\left(^{60}\right)$ A fim de que esta justa construção

59) Ver crítica à teoria dos elementos negativos do tipo: em Heleno Cláudio Fragoso, Conduta Punível, 1961, pág. 150 ss.

60) Ob. cit., pág. 369. 
prevalecesse entre nós, seria necessário reformular o art. 20, para permitir inclusive a isenção de pena para o erro de direito não censurável, acerca da proibição, reservando-se a atenuação especial para os casos em que exista somente diminuição de censura. Como está redigido, confudo, o dispositivo em questão conduz à uma intolerável presunção de culpa lacto sensu e, pois, à responsabilidade objetiva. 